\section{SOI: 1.1/TAS DOI: 10.15863/TAS International Scientific Journal Theoretical \& Applied Science}

p-ISSN: 2308-4944 (print)

e-ISSN: 2409-0085 (online)

Year: 2016

Issue: 6

Volume: 38

Published: 30.06 .2016

http://T-Science.org

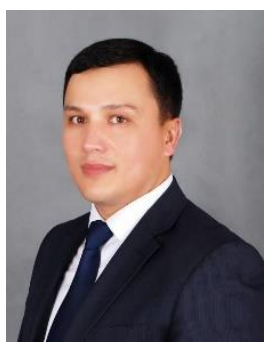

Mukhuddin B. Kalonov

Chief director

The uzbek agency for avtomobil and river transport. Dimm "Avtodaryotrans-ilm" Uzbekistan jamol_qambarov@mail.ru

SECTION 31. Economic research, finance, innovation, risk management.

\title{
ORGANIZATION OF ACCOUNTING AND COST ANALYSIS OF PROVISION OF CARS
}

Abstract: The article revealed issues of organization of accounting and analysis of the cost of providing services of cars. Classification of costs and methods of accounting and calculation. The results of the operations depend on the information that they use for planning, monitoring and control of management, and support decision making. The main criterion for effectiveness of the system is the efficient management of financial and human resources. Managerial Accounting provides the necessary information for this framework and mechanism for the implementation of this task.

Key words: organization, analysis of costs, management accounting, costs, vehicles.

Language: English

Citation: Kalonov MB (2016) ORGANIZATION OF ACCOUNTING AND COST ANALYSIS OF PROVISION OF CARS. ISJ Theoretical \& Applied Science, 06 (38): 134-136.

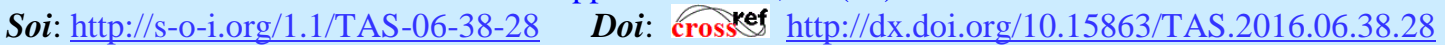

Management accounting is an area of expertise that are in demand by all involved in entrepreneurial activity in order to achieve the goals of their administration or the owner of the organization. The results of the activities depends on the information that they use for planning, monitoring and control of management, as well as support decision making. The value of this account is to systematically consider issues within the organization of operational planning, control and accounting of certain types of activities. The main criterion for the effectiveness of the system is the effective management of financial and human resources, and management accounting provides this essential information base and the mechanism of realization of this task.

Management is a kind of the accounting "rules of the game", developed individually for each company with all the features of its functioning. Among the characteristics of management accounting are the following: efficiency in the provision of management information; preparation of weekly and sometimes daily reports; the possibility of detail of information to the extent that the benefits of the information received is higher than the cost to develop it; analysis of the fait accompli of economic activities and planning for the next reporting periods. [1]

A significant role in managerial accounting is given account of costs and cost of goods (works, services). The success of the issue, and even the continued existence of economic entities are directly dependent on the feasibility of produced costs that need to be taken into account and must be promptly analyzed in order to reduce them. Therefore it is necessary to disclose the nature and content of concepts such as costs, expenses and costs.

These issues, along with issues of cost classification and methods of accounting and calculation will be discussed below. There will also be an objective necessity justified the feasibility of selection as an object of study accounting and analysis of transport and forwarding services costs, and will also be formulated approaches to the identification of the place and role of transport companies in the area of the national economy in the new conditions of its functioning.

In contrast to Marx's theory of marginalizes theory traditionally distinguishes four groups of factors: land, labor, capital, entrepreneurial activity [2].

The main differences between the two systems are as follows:

- Marxism is based on the fact that the factors of production as an economic category determined by the social orientation of production. Already in the original basis of the production process formed the class composition of society and the need for class struggle for "justice." 


\begin{tabular}{|c|c|c|c|c|c|c|}
\hline Impact Factor: & $\begin{array}{l}\text { ISRA (India) } \\
\text { ISI (Dubai, UAF } \\
\text { GIF (Australia) } \\
\text { JIF }\end{array}$ & $\begin{array}{l}=1.344 \\
=0.829 \\
=0.564 \\
=1.500\end{array}$ & $\begin{array}{l}\text { SIS (USA) } \\
\text { PИНЦ (Russia } \\
\text { ESJI (KZ) } \\
\text { SJIF (Morocco }\end{array}$ & $\begin{array}{l}=\mathbf{0 . 9 1 2} \\
=\mathbf{0 . 2 3 4} \\
=\mathbf{1 . 0 4 2} \\
=\mathbf{2 . 0 3 1}\end{array}$ & $\begin{array}{l}\text { ICV (Poland) } \\
\text { PIF (India) } \\
\text { IBI (India) }\end{array}$ & $\begin{array}{l}=6.630 \\
=1.940 \\
=4.260\end{array}$ \\
\hline
\end{tabular}

Marginalizes also consider factors such as the general technical and economic elements without which the production process is unthinkable ;

- Marginalizes under capital assets and understand the subject of work, and the natural conditions of release in a special fund. Marxists combine natural conditions, the means of labor and objects of labor in a single real factor ;

- If marginalizes recognize entrepreneurship as a factor of production, the Marxists deny it.

In general, the difference in the classification of the factors of production is mainly due - class approach to the analysis of natural production. In economic theory, post-industrial society as factors of production are allocated and environmental information. Both are closely linked with the achievements of modern science, which itself acts as an independent factor, as it has a decisive impact on the level of production efficiency, the process of preparing a skilled workforce, and improving human capital and capabilities. [3]

Modern economic theory under the cost understands "the monetary value of the costs of production factors necessary for the implementation of enterprise production and business activities related to the production and sales of products and provision of services, that is all, what it costs to the enterprise product production and sales (products)."

The relationship between the costs and expenses shown in the diagram (Shmalenbah ) .

Under neutral expenditure understand the costs, which do not meet any costs, they are divided into three categories :

- not related to this enterprise, characterized by the fact that the cost of consumption is not at all to do with the production of the final product (e.g., donations ) ;

- $\quad$ extremely costs are then, if they arise as a result of the production of the final product, but are so extreme that they can not be included in the cost, otherwise the cost of the period due to unexpected costs arising consumption will increase in the future can not be the basis of any planning for prices or to calculate prices or to establish the lower boundary of the price ;

- neutral costs that are caused by assessing the implications, if the expenses are greater than the amount of expenses based on their nature. This is the case when, for example, the amount of depreciation for financial accounting depreciation above, taken into account in management accounting. This is due to two reasons: either does not match the term of the fixed assets for management and financial accounting purposes, or basis for determining the depreciation is the cost of the original purchase (financial accounting) or the cost of a new purchase. Additional costs may arise in connection with the following circumstances: [4]

- $\quad$ patent for services available to an entrepreneur the factors of production are not considered as expenses, as an entrepreneur (sole proprietorship or partnership ) does not pay himself a salary for their work and for the use of the equity interest is compensation is contrary part of the profits.

The preparation of these funds are fully using the profits, not costs. In managerial accounting, as opposed to the wage (for individual companies and partnerships) and participation in the capital shall be included in the cost.

In the manufacture of products and provision of services must take into account not to periodically arising losses due to risky transactions in management accounting is carried out by means of calculation taking into account the risk premiums. Thus, there is "periodization costs", which do not occur periodically. In the period when there is no loss due to the risk, and no costs accrued risk premiums are in full incremental costs. If there is a loss on such transactions, it is recognized as extraordinary expenses and not taken into account in management accounting.

Just as in the case with neutral charges have additional costs (costs accrued types that exceed the related costs), together with cost. Take, for example, the case where the financial accounting period of the fixed assets is greater than the internal data of the company for the purpose of management accounting.

For example, the depreciation charge for the purposes of the balance sheet amount to DM 1000.00 per year, and for internal accounting DM 1500,00 , in this case, the additional costs would amount to DM 500,00. Furthermore, the controversial issue discussed by German scientists is a necessary economic sense to invest in the concept of "cost." Within the delineation of the payment terms, costs and expenses allocated cost approach to the definition of "cost". Along with the treatment of the value of the concept of costs in the economic literature of Germany, there is a different approach to the determination of costs. The basis of the terminological differences of concepts is that different authors pursued in determining the goals and concepts of unequal choose different theoretical background for his argument. On this basis it is not surprising that there are many interpretations of the term. [ 5 ]

We believe this is the most comprehensive definition, while making three significant observations on this concept:

- It must necessarily go consumption property. At the same time a property is necessary to 


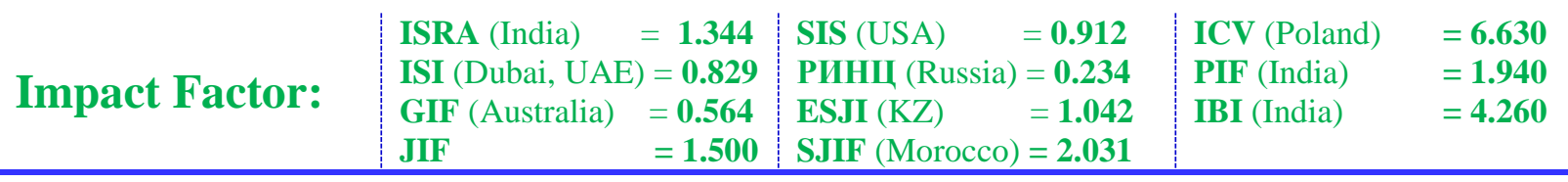

understand all the available valuation used objects, not just real estate, services and rights, but also nominal assets such as money or loan amount of financial capital. In addition, the use is understood not only as a physical consumption of raw materials, but as productivity and utilities, the space-time use of the means of production and rights. To use property rank as well as the payment of official fees, in particular taxes. We are talking about the consumption of property in the general sense of the word, if the property in accordance with its participation in the process of production of the final product is completely or partially loses its properties, so that you can use to overcome the problems alternatively implemented ;

- Consumption property must apply to the manufacturing process. Not every property consumption is a matter of cost accounting, and only required for manufacturing purposes and assess the results and production organization to maintain productivity. For example, for the main purpose of the brewery - beer production and sales. At the shoe factory main purpose is defined in the proposed range of footwear. Costs considered only a consumption of this terminology, which will inevitably arise in the implementation of the main objectives. If this is not close to the target, ie, the costs do not arise in the performance of production targets, the question of costly nature of such expenses is not. In this case we speak of non-productive expenditure.

- Need valuation consumption. This observation is different from that in the first two signs of the level. If the first two specifies that should be taken into consideration relating to the production process of the product consumption. Third - how to embrace and reflect the economic sense of the real use ', the value of money.

Relating to the production process of property consumption should be reflected in monetary terms, as the heterogeneous levels of consumption can not be directly added together.

\section{References:}

1. Terekhov VA (1997) Analytical accounting: state and problems // Accounting. - 1997. № 3. - pp. 86-89.

2. Terekhova VA (1996) General methodological principles for the use of standardization in management accounting // Accounting. - 1996. - № 11. - pp.55-57.

3. Trofimova LA (1966) Once again on the allocation of overheads fleets // Accounting. - 1966. - №7. - pp.65-66.

4. Shishkova TB (1996) Managerial and financial accounting: a comparative aspect // Accounting. - 1996. - №3. - pp.52-56.

5. Koch H (1958) Zur Diskussion ueber den Kostenbegriff // Zeitschrift fuer handelswissenschaftliche Forschung. 1958. - № 10. - pp. 355-399.

6. Nerush YM (1997) Logistics:. - Moscow: Banks and exchange, UNITY -DANA, 1997. - $271 \mathrm{p}$.
7. Nikolaichuk VE (2001) Logistika . - SPb .: Peter, 2001 .- 160 p.

8. Nikolaeva SA (1998) Principles of formation and calculation of the cost . Moscow: Research Press, 1998. - 109 p.

9. (2003) Organization of transport to the application of the principles of logistics. Coll. scientific papers . - SPb . : SPbGIEU . 2003. $-219 \mathrm{p}$.

10. Persianov VA (1996) Integrated transport system: Textbook / Ed . VG Galaburdy.Moscow: Transport , 1996 . - 294 p.

11. Parahina VN, Maksimenko LS, Panasenko SV (2007) Strategic menedzhment. Moscow: KNORUS ., 2007.

12. Knorring VI (2007) Theory, practice and art upravleniya.Uchebnik for VUZov. Moscow: NORM ., 2007. 